\section{ANALISIS PENGAKUAN, PENGUKURAN DAN PENGUNGKAPAN IMBALAN PASCA KERJA BERDASARKAN PSAK NO. 24 (REVISI 2013) DAN DAMPAK PERUBAHANNYA TERHADAP LAPORAN KEUANGAN PADA PERUSAHAAN YANG TERDAFTAR DALAM BURSA EFEK INDONESIA}

\author{
Dila Nurul Fadillah dan Triandi \\ Program Studi Akuntansi, Institut Bisnis dan Informatika Kesatuan \\ Bogor, Indonesia \\ E-mail:lemlit@stiekesatuan.ac.id
}

\begin{abstract}
Every established company certainly hopes that the company can grow rapidly, advance and have a long life. The survival of a company depends very much on what the company produces through the performance of the workers in the company. A worker will give a maximum performance if they get satisfaction from the results of their work. The satisfaction of these workers can be given through employee benefits that are appropriate for their work. With employee benefits, workers will provide maximum and good performance and have a sense of loyalty to the company.

The purpose of this study was to find out how the application of PSAK No.24 (revised 2013) regarding post-employment benefits in a company, the suitability of recognition, measurement and disclosure and the impact of the application of PSAK No. 24 (Revised 2013). The author conducted research at PT. Indonesian Telecommunications. Tbk and PT. Blue Bird.Tbk.

The results of the study show that the two companies have implemented postemployment benefits in accordance with PSAK No.24 (revised 2013). PT Telekomunikasi Indonesia.TbK implements both post-employment benefits programs, namely defined benefits and definite contributions, while for PT. Bird Bird.Tbk only implements a defined contribution program. Because both companies have implemented PSAK No. 24 (Revised 2013) which took effect on January 1, 2015 then the financial statements of the two companies must be reviewed. Therefore, both companies should maintain their consistency in implementing PSAK No.24 in accordance with the applicable regulations. Because employee benefits are a large operating expenses of the company and can affect the company's profit.
\end{abstract}

Keywords: PSAK No. 24 (revised 2013) and post-employment benefits

\section{PENDAHULUAN}

Tujuan didirikannya perusahaan adalah mengembangkan usaha sehingga memiliki keberlangsungan hidup dalam jangka panjang. Keberlangsungan hidup perusahaan sangat dipengaruhi oleh dukungan kinerja dari semua pihak yang terlibat dalam mendukung aktivitas perusahaan. Pekerja akan memberikan kinerja yang maksimal jika perusahaan memperhatikan imbal kerja yang sewajarnya, disesuaikan dengan hasil pekerjaannya. Melalui imbalan kerja yang sesuai, diharapkan pekerja akan memberikan kinerja yang maksimal serta loyal terhadap pekerjaannya.
Analisis

Pengakuan,

Pengukuran dan

Pengungkapan

Imbalan Pasca

Kerja

Berdasarkan

PSAK No. 24

(revisi 2013) dan

Dampak

Perubahannya

terhadap

Laporan

Keuangan Pada

Perusahaan Yang

Terdaftar Dalam

Bursa efek

Indonesia

246

Submitted:

MEI 2019

Accepted: OKTOBER 2019

\footnotetext{
JIAKES

Jurnal Ilmiah Akuntansi Kesatuan Vol. 7 No 2, 2019 pg. $246-257$ IBI Kesatua ISSN $2337-7852$
} 
Analisis

Pengakuan,

Pengukuran dan

Pengungkapan

Imbalan Pasca

Kerja

Berdasarkan

PSAK No. 24

(revisi 2013) dan

Dampak

Perubahannya

terhadap

Laporan

Keuangan Pada

Perusahaan

Yang Terdaftar

Dalam Bursa

efek Indonesia

Imbalan pasca kerja adalah imbalan yang diberikan perusahaan kepada pekerja pada saat perusahaan melakukan pemutusan hubungan kerja. Pembayaran imbalan pasca kerja, biasanya dilakukan langsung dengan uang tunai atau dengan non tunai, seperti : dalam bentuk dana pensiun, asuransi, opsi, saham dan lain-lain. (Marisi:2005).

Dalam PSAK No. 24 (revisi 2010) tanggal 1 Januari 2012, terdapat beberapa komponen beban pensiun seperti : biaya jasa kini, biaya jasa lalu, amortisasi keuntungan atau kerugian aktuaria (jika melebihi koridor), bunga dan hasil yang diharapkan dari aset program, serta dampak dari kurtailmen atau penyelesaian program. Ada dua hal yang diperbaharui dari PSAK No. 24 (revisi 2010), yaitu : amortisasi keuntungan atau kerugian aktuaria dan hasil yang diharapkan dari aset program. Pada tanggal 1 Januari 2015 Dewan Standar Akuntansi Keuangan telah menerbitkan kembali PSAK No.24 (Revisi 2013), dimana beban pensiun yang akan diakui dalam laba rugi dihitung berdasarkan beban jasa kini, biaya jasa lalu, keuntungan dan kerugian penyelesaian dan bunga neto atas liabilitas (aset) imbalan pasti neto. Menurut PSAK No. 24 (rev 2013, par 3) "standar akuntansi yang mengacu pada International Financial Reporting Standards dan dibahas dalam International Accounting Standards (IAS) 19 mengenai Employee Benefit yang mulai efektif diberlakukan pada tanggal 1 Januari 2013”.

Adanya perubahan tersebut tentu akan berdampak kepada pengakuan, pengukuran dan pengungkapan imbalan pasca kerja. Artinya perusahaan harus menghitung ulang liabilitas imbalan pasca kerja sesuai ketentuan yang baru. Hal ini akan berdampak kepada perubahan penyajian nilai liabilitas dan ekuitas dalam laporan posisi keuangan, diharapkan perubahan ini akan mempermudah pengguna dalam melakukan penilaian terhadap imbalan manfaat pasti.

\section{TINJAUAN PUSTAKA}

Imbalan Kerja

Imbalan kerja menurut PSAK No.24 (rev 2013, par 8) adalah "seluruh bentuk imbalan yang diberikan, baik terhadap pertukaran jasa yang diberikan pekerja atau untuk pemutusan hubungan kontrak kerja.

Jenis imbalan kerja dapat dibedakan menjadi :

1. Imbalan kerja jangka pendek

2. Imbalan pasca kerja

3. Imbalan kerja jangka panjang lain

4. Pesangon.

sedangkan untuk jenis program imbalan pasca kerja adalah : program iuran pasti dan program imbalan pasti

Tabel 1

Perbandingan Program Iuran Pasti dengan Program Imbalan Pasti

\begin{tabular}{|l|l|l|}
\hline & \multicolumn{1}{|c|}{ Program Iuran Pasti } & \multicolumn{1}{c|}{ Program Imbalan Pasti } \\
\hline Besaran Iuran & Tetap (Ditentukan) & Tidak Ditentukan \\
\hline Besaran Imbalan & Tidak Ditentukan & Tetap (Ditentukan) \\
\hline $\begin{array}{l}\text { Kewajiban } \\
\text { Entitas }\end{array}$ & $\begin{array}{l}\text { Tergantung kepada Iuran } \\
\text { yang Disepakati }\end{array}$ & $\begin{array}{l}\text { Tergantung kepada Imbalan } \\
\text { yang Disepakati }\end{array}$ \\
\hline Risiko Aktuarial & Ditanggung oleh Pekerja & $\begin{array}{l}\text { Ditanggung oleh Pemberi } \\
\text { Kerja }\end{array}$ \\
\hline Risiko Investasi & Ditanggung oleh Pekerja & $\begin{array}{l}\text { Ditanggung oleh Pemberi } \\
\text { Kerja }\end{array}$ \\
\hline
\end{tabular}

Sumber: Dwi Martani, 2016:291 
1. Sebagai liabilitas, setelah dikurangi dengan iuran yang telah dibayar. Jika iuran tersebut melebihi iuran terutang untuk jasa sebelum akhir periode pelaporan, maka perusahaan mengakui kelebihan tersebut sebagai aset (beban dibayar dimuka), sepanjang kelebihan tersebut mengurangi pembayaran iuran masa depan atau dikembalikan; dan

2. Sebagai Beban, kecuali jika pernyataan ini mensyaratkan atau mengizinkan iuran, termasuk dalam biaya peroleh aset.

Untuk memenuhi perlakuan akuntansi, terlebih dahulu harus dipahami dua komponen utama dari program imbalan pasti, yaitu : kewajiban imbalan pasti dan aset program.

Menurut PSAK 24 (revisi 2013) asumsi aktuaria terdiri dari:

1. Asumsi demografik mengenai karakteristik masa depan dari pekerja dan mantan pekerja yang berhak atas imbalan.

Asumsi demografi berhubungan dengan masalah seperti:

a. Mortalitas;

b. Tingkat perputaran pekerja, cacat dan pensiun dini;

c. Proporsi dari peserta program dengan tanggungannya yang akan berhak atas imbalan;

d. Proporsi dari peserta program yang akan memilih setiap bentuk opsi pembayaran yang tersedia berdasarkan persyaratan program; dan

e. Tingkat klaim dalam program kesehatan.

2. Asumsi keuangan, berhubungan dengan hal-hal seperti:
a. Tingkat diskonto;
b. Level imbalan;
c. Dalam hal imbalan kesehatan; dan
d. Pajak terutang.

Analisis

Pengakuan,

Pengukuran dan

Pengungkapan

Imbalan Pasca

Kerja

Berdasarkan

PSAK No. 24

(revisi 2013) dan

Dampak

Perubahannya

terhadap

Laporan

Keuangan Pada

Perusahaan

Yang Terdaftar

Dalam Bursa

efek Indonesia

\section{METODE PENELITIAN}

Metode analisis yang digunakan dalam penelitian ini adalah metode deskriptif komparatif. Populasi dalam penelitian ini adalah seluruh perusahaan yang terdaftar di Bursa Efek Indonesia, sedang perusahaan yang dijadikan sampel dalam penelitian ini adalah PT Telekomunikasi Indonesia.Tbk dan PT Blue Bird.Tbk.

\section{HASIL DAN PEMBAHASAN}

Berikut adalah kesesuaian pengakuan dan pengukuran pada PT Telekomunikasi Indonesia.Tbk

Tabel 2

Kesesuaian Pengakuan dan pengukuran

\begin{tabular}{|l|l|l|}
\hline \multicolumn{1}{|c|}{ Keterangan } & \multicolumn{1}{|c|}{ PSAK No. 24 } & PT . Telekomunikasi Indonesia.Tbk \\
\hline $\begin{array}{l}\text { Beban Pensiun } \\
\text { yang diakui di }\end{array}$ & Biaya Jasa Kini & $\begin{array}{l}\text { Biaya jasa kini diakui untuk estimasi } \\
\text { Laba Rugi }\end{array}$ \\
\cline { 2 - 3 } & Biaya Jasa Lalu & $\begin{array}{l}\text { Biaya jasa lalu diakui jika telah } \\
\text { menjadi hak (Vested) atau } \\
\text { diamortisasi selama periode vesting } \\
\text { (Tahun 2013 dan 2014) }\end{array}$ \\
\hline
\end{tabular}


Analisis

Pengakuan,

Pengukuran dan

Pengungkapan

Imbalan Pasca

Kerja

Berdasarkan

PSAK No. 24

(revisi 2013) dan

Dampak

Perubahannya

terhadap

Laporan

Keuangan Pada

Perusahaan

Yang Terdaftar

Dalam Bursa

efek Indonesia

\begin{tabular}{|c|c|c|}
\hline & & $\begin{array}{l}\text { Biaya jasa lalu diakui di laba rugi } \\
\text { pada tanggal awal: } \\
\text { a. Ketika amandemen atau } \\
\text { kurtailmen program; } \\
\text { b. Ketika grup mengakui biaya } \\
\text { restrukturisasi terkait (Tahun } \\
\text { 2015) }\end{array}$ \\
\hline $\begin{array}{l}\text { Perhitungan } \\
\text { bunga neto }\end{array}$ & $\begin{array}{l}\text { Bunga neto atas } \\
\text { liabilitas (aset) } \\
\text { imbalan pasti neto }\end{array}$ & $\begin{array}{l}\text { Bunga neto dihitung dengan } \\
\text { mengalikan liabilitas (aset) imbalan } \\
\text { pasti neto dengan tingkat diskonto. }\end{array}$ \\
\hline \multirow[t]{2}{*}{$\begin{array}{l}\text { Pengakuan } \\
\text { kerugian atau } \\
\text { keuntungan } \\
\text { aktuarial }\end{array}$} & $\begin{array}{l}\text { Dampak dari } \\
\text { Kurtailmen }\end{array}$ & $\begin{array}{l}\text { Laba atau rugi kurtailmen diakui } \\
\text { apabila terdapat komitmen untuk } \\
\text { melakukan pengurangan jumlah } \\
\text { karyawan. }\end{array}$ \\
\hline & $\begin{array}{l}\text { keuntungan dan } \\
\text { kerugian aktuarial } \\
\text { sampai pada batas } \\
\text { koridor akan diakui } \\
\text { menambah atau } \\
\text { mengurangi liabilitas } \\
\text { imbalan kerja. }\end{array}$ & $\begin{array}{l}\text { Laba atau rugi aktuaria yang timbul } \\
\text { dari adanya penyesuaian yang dibuat } \\
\text { berdasarkan perubahan asumsi } \\
\text { aktuaria, yang melebihi nilai } \\
\text { tertinggi antara } 10 \% \text { dari NKKIP atau } \\
\text { NWAP, dibebankan atau dikreditkan } \\
\text { terhadap laporan laba rugi } \\
\text { komprehensif selasa sisa masa kerja }\end{array}$ \\
\hline $\begin{array}{l}\text { Metode yang } \\
\text { digunakan }\end{array}$ & Projected Unit Credit & Projected Unit Credit \\
\hline $\begin{array}{l}\text { Asumsi } \\
\text { Aktuaria }\end{array}$ & $\begin{array}{l}\text { Asumsi untuk } \\
\text { membuat estimasi } \\
\text { andal }\end{array}$ & $\begin{array}{l}\text { Asumsi yang digunakan: } \\
\text { a. Tingkat diskonto } \\
\text { b. Taksiran Tingkat pengembalian } \\
\text { jangka panjang } \\
\text { c. Tingkat Kenaikan Kompensasi }\end{array}$ \\
\hline $\begin{array}{l}\text { Pengukuran } \\
\text { kembali }\end{array}$ & $\begin{array}{l}\text { Menentukan } \\
\text { pengukuran kembali } \\
\text { atas liabilitas (aset) } \\
\text { imbalan pasti neto, } \\
\text { yang akan diakui } \\
\text { sebagai penghasilan } \\
\text { komprehensif lain }\end{array}$ & $\begin{array}{l}\text { Pengukuran kembali, terdiri dari } \\
\text { keuntungan dan kerugian aktuarial, } \\
\text { dampak batas atas aset (tidak } \\
\text { termasuk jumlah yang dimasukkan } \\
\text { dalam bunga neto atas liabilitas } \\
\text { (aset) imbalan pasti neto) dan imbal } \\
\text { hasil aset program (tidak termasuk } \\
\text { jumlah yang dimasukkan dalam } \\
\text { bunga neto atas liabilitas (aset) } \\
\text { imbalan pasti neto) diakui pada } \\
\text { ekuitas melalui penghasilan } \\
\text { komprehensif lain di periode } \\
\text { terjadinya. Pengukuran kembali tidak } \\
\text { diklasifikasikan ke laba rugi di } \\
\text { periode selanjutnya. }\end{array}$ \\
\hline
\end{tabular}


Tabel 3

Kesesuaian Gambaran Umum

Analisis

Pengakuan,

\begin{tabular}{l|l|l|}
\hline Keterangan & \multicolumn{1}{|c|}{ PSAK No. 24 } & PT. Telekomunikasi Indonesia.Tbk \\
\hline $\begin{array}{l}\text { Gambaran } \\
\text { Umum }\end{array}$ & Jenis Program Imbalan & Jenis Program Imbalan Pasca Kerja \\
Jenis & Pasca Kerja terbagi & terbagi menjadi 2: \\
Program & $\begin{array}{l}\text { a. Iuran Pasti } \\
\text { b. Imbalan Pasti }\end{array}$ & a. Iuran pasti (Funded) \\
& b. Imbalan pasti (Funded,unfunded) \\
\hline
\end{tabular}

Pengukuran dan

Pengungkapan

Imbalan Pasca

Kerja

Berdasarkan

PSAK No. 24

(revisi 2013) dan

Dampak

Berikut Program pensiun yang digunakan pada PT. Telekomunikasi Indonesia.Tbk:

a. Pensiun dan Imbaan Pasca Kerja Lainnya

1) Beban manfaat pensiun dibayar dimuka

2) Liabilitas diestimasi manfaat pensiun

i. Perusahaan Telkom

ii. Telkomsel

3) Imbalan Pasca Kerja Lainnya

b. Imbalan Kesehatan Pasca Kerja

Perubahannya

terhadap

Laporan

Keuangan Pada

Perusahaan

Yang Terdaftar

Dalam Bursa

efek Indonesia

1. Jumlah yang diakui dalam Laba Rugi

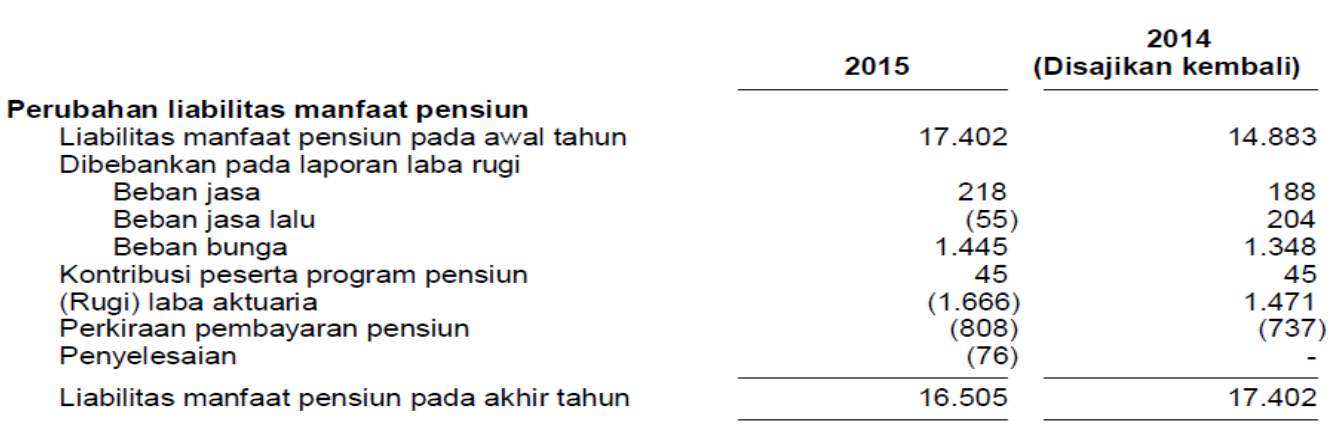

Gambar 1

Jumlah yang diakui dalam laba rugi

Tabel 4

Kesesuaian Beban Yang Diakui Dalam Laba Rugi

\begin{tabular}{|c|c|c|}
\hline Keterangan & PSAK No. 24 & $\begin{array}{l}\text { PT. Telekomunikasi } \\
\text { Indonesia.Tbk }\end{array}$ \\
\hline \multirow{5}{*}{$\begin{array}{lr}\text { Yang } & \text { diakui } \\
\text { dalam } & \text { laba } \\
\text { rugi } & \end{array}$} & Biaya jasa kini & Biaya Jasa \\
\hline & Biaya jasa lalu & Biaya Jasa Lalu \\
\hline & $\begin{array}{l}\text { keuntungan kerugian atas } \\
\text { penyelesaian }\end{array}$ & $\begin{array}{l}\text { keuntungan kerugian atas } \\
\text { penyelesaian }\end{array}$ \\
\hline & $\begin{array}{l}\text { bunga neto atas liabilitas } \\
\text { (aset) imbalan pasti neto }\end{array}$ & Beban Bunga \\
\hline & $\begin{array}{l}\text { menentukan pengukuran } \\
\text { kembali }\end{array}$ & $\begin{array}{l}\text { Menentukan pengukuran } \\
\text { kembali }\end{array}$ \\
\hline
\end{tabular}

2. Jumlah yang dilaporkan dalam pendapatan komprehensif lain

Didalam PSAK No. 24 (revisi 2013) penangguhan pengakuan keuntungan dan kerugian aktuaria tidak diizinkan. Keuntungan dan kerugian aktuaria langsung diakui dalam OCI. Dalam hal ini PT. Telekomunikasi Indonesia.Tbk telah menerapkan hal 
Analisis

Pengakuan,

Pengukuran dan

Pengungkapan

Imbalan Pasca

Kerja

Berdasarkan

PSAK No. 24

(revisi 2013) dan

Dampak

Perubahannya terhadap

Laporan

Keuangan Pada

Perusahaan

Yang Terdaftar

Dalam Bursa

efek Indonesia

\section{1}

Dampak Penerapan PSAK No. 24 (Revisi 2013) sangat berdampak kepada :

1. Perhitungan beban pensiun;

2. Pengakuan keuntungan kerugian aktuaria;

3. Pengungkapan.

Akibat adanya perubahan tersebut perusahaan, menyajikan laporan posisi keuangan tiga tahun komparatif yaitu tahun 2015, komparasi tahun 2014 dan 2013. PT Telekomunikasi Indonesia. Tbk sudah menerapkan PSAK 24 (2013) secara retrospektif pada periode berjalan. Sebagai akibat dari perubahan tersebut, saldo komparatif dalam laporan keuangan konsolidasi disajikan sebagai berikut:

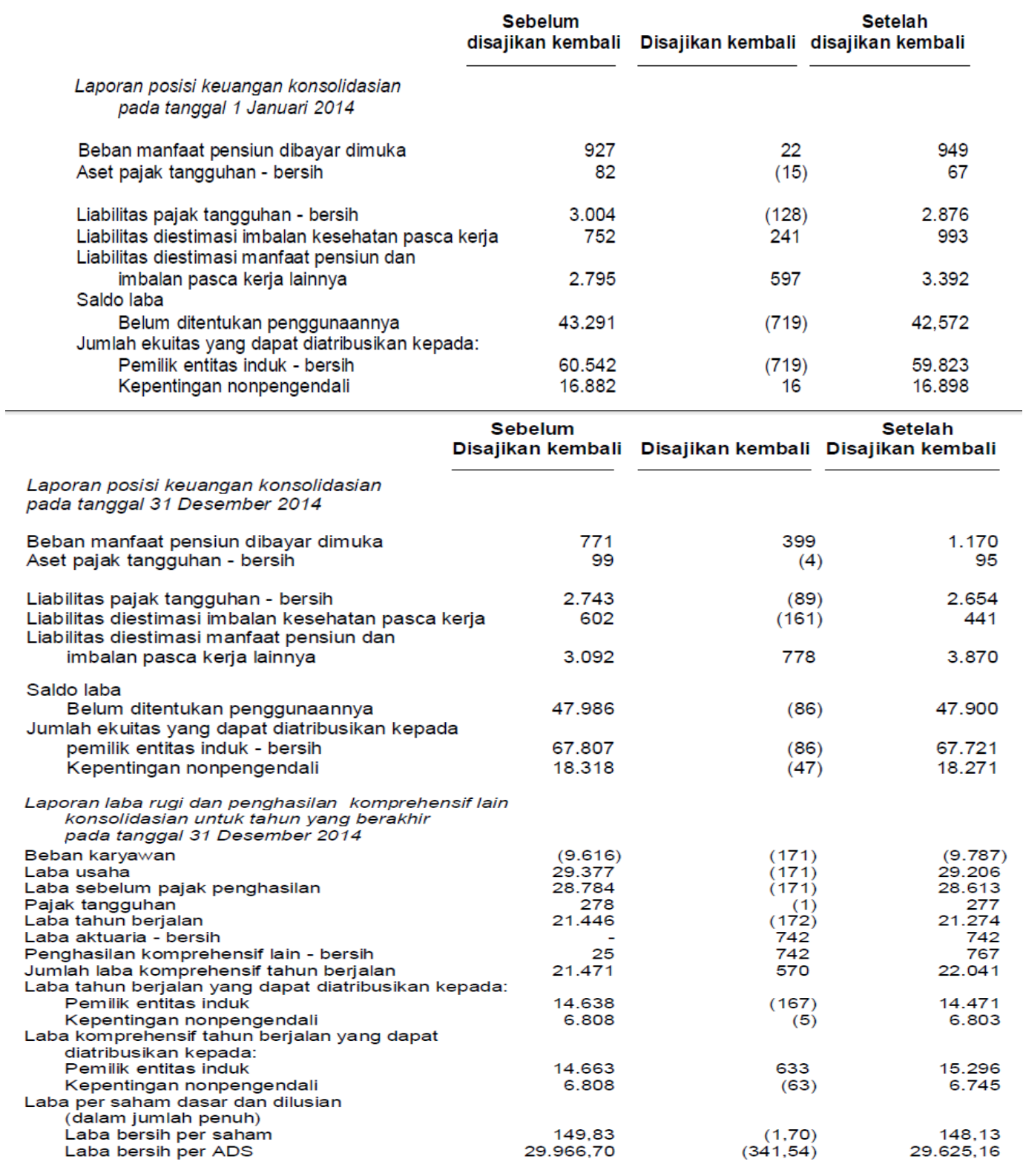

Gambar 2

Penyajian Kembali Laporan Keuangan Kesesuaian Pengakuan dan Pengukuran pada PT Blue Bird.Tbk 
Tabel 5

Kesesuaian Pengakuan dan pengukuran

\begin{tabular}{|c|c|c|}
\hline Keterangan & PSAK No. 24 & PT. Blue Bird.Tbk \\
\hline \multirow{3}{*}{$\begin{array}{l}\text { Beban } \\
\text { Pensiun yang } \\
\text { diakui di } \\
\text { Laba Rugi }\end{array}$} & Biaya Jasa Kini & $\begin{array}{l}\text { Biaya jasa kini diakui untuk estimasi } \\
\text { yang akan diperoleh karyawan }\end{array}$ \\
\hline & \multirow[t]{2}{*}{ Biaya Jasa Lalu } & $\begin{array}{l}\text { Biaya jasa lalu atas pengenalan } \\
\text { program manfaat pasti atau perubahan } \\
\text { utang imbalan dari program yang ada } \\
\text { diamortisasi dengan metode garis } \\
\text { lurus sepanjang periode sampai } \\
\text { imbalan tersebut menjadi hak atau } \\
\text { vested. }\end{array}$ \\
\hline & & $\begin{array}{l}\text { Biaya jasa lalu diakui di laba rugi pada } \\
\text { tanggal awal: } \\
\text { a. Ketika amandemen atau kurtailmen } \\
\text { program; } \\
\text { b. Ketika grup mengakui biaya } \\
\text { restrukturisasi terkait (thn 2015) }\end{array}$ \\
\hline $\begin{array}{l}\text { Perhitungan } \\
\text { bunga neto }\end{array}$ & $\begin{array}{l}\text { Bunga neto atas } \\
\text { liabilitas (aset) } \\
\text { imbalan pasti neto }\end{array}$ & $\begin{array}{l}\text { Bunga neto dihitung dengan } \\
\text { mengalikan liabilitas (aset) imbalan } \\
\text { pasti neto dengan tingkat diskonto. }\end{array}$ \\
\hline \multirow[t]{2}{*}{$\begin{array}{l}\text { pengakuan } \\
\text { kerugian atau } \\
\text { keuntungan } \\
\text { aktuarial }\end{array}$} & $\begin{array}{l}\text { Menentukan } \\
\text { keuntungan kerugian } \\
\text { ketika suatu prgram } \\
\text { dibatasi }\end{array}$ & $\begin{array}{l}\text { Keuntungan atau kerugian atas } \\
\text { kurtailmen atau penyelesaian suatu } \\
\text { program imbalan pasti diakui ketika } \\
\text { kurtailmen atau penyelesaian terjadi. }\end{array}$ \\
\hline & $\begin{array}{l}\text { keuntungan dan } \\
\text { kerugian aktuarial } \\
\text { sampai pada batas } \\
\text { koridor akan diakui } \\
\text { menambah atau } \\
\text { mengurangi liabilitas } \\
\text { imbalan kerja. }\end{array}$ & $\begin{array}{l}\text { Keuntungan atau kerugian aktuarial } \\
\text { diakui sebagai penghasilan atau beban } \\
\text { apabila akumulasi keuntungan atau } \\
\text { kerugian aktuarial bersih yang belum } \\
\text { diakui pada akhir tahun pelaporan } \\
\text { sebelumnya melebihi 10\% dari nilai } \\
\text { kini kewajiban imbalan pasti pada } \\
\text { tanggal tersebut. Keuntungan atau } \\
\text { kerugian ini diakui dengan } \\
\text { menggunakan metode garis lurus } \\
\text { berdasarkan rata-rata sisa masa kerja } \\
\text { karyawan yang diperkirakan. }\end{array}$ \\
\hline $\begin{array}{l}\text { Metode yang } \\
\text { digunakan }\end{array}$ & Projected Unit Credit & Projected Unit Credit \\
\hline $\begin{array}{l}\text { Asumsi } \\
\text { Aktuaria }\end{array}$ & $\begin{array}{l}\text { Asumsi untuk } \\
\text { membuat estimasi } \\
\text { andal }\end{array}$ & $\begin{array}{l}\text { Asumsi yang digunakan: } \\
\text { a. Tingkat diskonto } \\
\text { b. Tingkat kenaikan gaji tahunan } \\
\text { c. Tingkat pengunduran diri } \\
\text { karyawan } \\
\text { d. Tingkat cacat } \\
\text { e. Umur pensiun } \\
\text { f. Tingkat kematian }\end{array}$ \\
\hline $\begin{array}{l}\text { Pengukuran } \\
\text { kembali }\end{array}$ & $\begin{array}{l}\text { Menentukan } \\
\text { pengukuran kembali } \\
\text { atas liabilitas (aset) }\end{array}$ & $\begin{array}{l}\text { Pengukuran kembali, terdiri dari } \\
\text { keuntungan dan kerugian aktuarial, } \\
\text { dampak batas atas aset (tidak termasuk }\end{array}$ \\
\hline
\end{tabular}

Analisis

Pengakuan,

Pengukuran dan

Pengungkapan

Imbalan Pasca

Kerja

Berdasarkan

PSAK No. 24

(revisi 2013) dan

Dampak

Perubahannya

terhadap

Laporan

Keuangan Pada

Perusahaan

Yang Terdaftar

Dalam Bursa

efek Indonesia 


\begin{tabular}{|c|c|c|}
\hline $\begin{array}{l}\text { Analisis } \\
\text { Pengakuan, } \\
\text { Pengukuran dan } \\
\text { Pengungkapan } \\
\text { Imbalan Pasca } \\
\text { Kerja } \\
\text { Berdasarkan } \\
\text { PSAK No. } 24 \\
\text { (revisi 2013) dan } \\
\text { Dampak } \\
\text { Perubahannva }\end{array}$ & $\begin{array}{l}\text { imbalan pasti neto, } \\
\text { yang akan diakui } \\
\text { sebagai penghasilan } \\
\text { komprehensif lain }\end{array}$ & $\begin{array}{l}\text { jumlah yang dimasukkan dalam bunga } \\
\text { neto atas liabilitas (aset) imbalan pasti } \\
\text { neto) dan imbal hasil aset program } \\
\text { (tidak termasuk jumlah yang } \\
\text { dimasukkan dalam bunga neto atas } \\
\text { liabilitas (aset) imbalan pasti neto) } \\
\text { diakui pada ekuitas melalui } \\
\text { penghasilan komprehensif lain di } \\
\text { periode terjadinya. Pengukuran } \\
\text { kembali tidak diklasifikasikan ke laba } \\
\text { rugi di periode selanjutnya. }\end{array}$ \\
\hline
\end{tabular}

terhadap

Laporan

Keuangan Pada

Perusahaan

Yang Terdaftar

Dalam Bursa

efek Indonesia

Kesesuaian Pengungkapan

1. Gambaran Umum Jenis Program

Tabel 6

Gambaran Umum PT. Blue Bird

\begin{tabular}{|l|l|l|}
\hline Keterangan & \multicolumn{1}{|c|}{ PSAK No. 24 } & \multicolumn{1}{|c|}{ PT. Blue Bird.Tbk } \\
\hline Gambaran & Jenis Program Imbalan & Jenis Program Imbalan Pasca Kerja \\
Umum & Pasca Kerja terbagi & terbagi menjadi 2: \\
Jenis & menjadi 2: & a. Imbalan Pasti \\
Program & $\begin{array}{l}\text { a. Iuran Pasti } \\
\text { b. Imbalan Pasti }\end{array}$ & \\
\hline
\end{tabular}

2. Total Beban Yang Diakui di Laporan Laba Rugi

Tabel 7

Beban Yang Diakui Di Laba Rugi PT. Blue Bird

\begin{tabular}{|c|c|c|}
\hline Keterangan & PSAK No. 24 & PT. Blue Bird.Tbk \\
\hline $\begin{array}{l}\text { Beban Yang } \\
\text { Diakui Di Laba } \\
\text { Rugi }\end{array}$ & $\begin{array}{l}\text { Beban yang diakui di } \\
\text { PSAK (Revisi 2010) } \\
\text { a. Biaya Jasa kini } \\
\text { b. Biaya Jasa Lalu } \\
\text { c. Amortisasi keuntungan } \\
\text { kerugian aktuarial } \\
\text { d. Dampak dari } \\
\text { kurtailmen }\end{array}$ & $\begin{array}{l}\text { Beban yang di akui di Laba } \\
\text { Rugi Oleh PT. Blue Bird.Tbk } \\
\text { a. Beban Jasa Kini } \\
\text { b. Beban Bunga } \\
\text { c. Amortiasi biaya jasa lalu } \\
\text { d. Amortisasi laba aktuaria }\end{array}$ \\
\hline & $\begin{array}{l}\text { Beban yang diakui di } \\
\text { PSAK (Revisi 2013) } \\
\text { a. Beban jasa kini } \\
\text { b. Beban Jasa Lalu } \\
\text { c. Keuntungan dan } \\
\quad \text { kerugian penyelesaian } \\
\text { bunga neto }\end{array}$ & $\begin{array}{l}\text { Beban yang di akui di Laba } \\
\text { Rugi Oleh PT. Blue } \\
\text { Bird.Tbk } \\
\text { a. Beban Jasa kini } \\
\text { b. Beban Bunga }\end{array}$ \\
\hline
\end{tabular}


3. Pengakuan Jumlah yang diakui dalam Komprehensif lain

Pengakuan jumlah dalam komprehensif lain yang diterapkan PSAK No. 24 (revisi 2013) telah diterapkan oleh PT. Blue Bird. Tbk. penghasilan komprehensif lain tidak dapat diakui dalam laporan laba rugi. Berbeda dengan PSAK No. 24 (Revisi 2010) yang masih menggunakan pendekatan koridor.

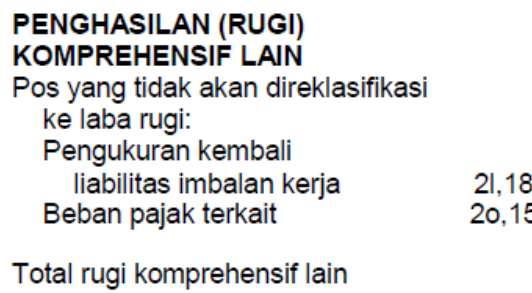

20,15

\begin{tabular}{rrr}
$(3.779)$ & $(7.163)$ \\
945 & & 1.791 \\
$(2.834)$ & $(5.372)$ \\
\hline
\end{tabular}

Gambar 3

Penyajian Penghasilan Rugi Komprehensif Lain

Dampak Penerapan PSAK No. 24 (Revisi 2013)

Dampak dari penerapan PSAK No.24 (Revisi 2013) berpengaruh terhadap penyajian laporan keuangan. Laporan keuangan akan disaji ulang untuk tiga tahun komparatif.

Gambar di bawah ini memperlihatkan dampak penyesuaian atas penyajian kembali terhadap laporan keuangan konsolidasian:
Analisis

Pengakuan,

Pengukuran dan

Pengungkapan

Imbalan Pasca

Kerja

Berdasarkan

PSAK No. 24

(revisi 2013) dan

Dampak

Perubahannya terhadap

Laporan

Keuangan Pada

Perusahaan

Yang Terdaftar

Dalam Bursa

efek Indonesia
LAPORAN POSISI KEUANGAN KONSOLIDASIAN:

LIABILITAS JANGKA PANJANG Liabilitas pajak tangguhan - neto Liabilitas imbalan kerja
31 Desember 2014/December 31, 2014

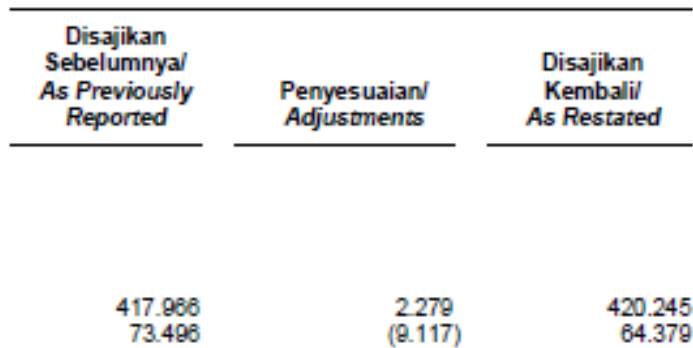

31 Desember 2014/December 31, 2014

\begin{tabular}{|c|c|c|}
\hline $\begin{array}{c}\text { Disajikan } \\
\text { Sebelumnyal } \\
\text { As Previously } \\
\text { Reported }\end{array}$ & $\begin{array}{l}\text { Penyesuaiand } \\
\text { Adjustments }\end{array}$ & $\begin{array}{l}\text { Disajikan } \\
\text { Kembalil } \\
\text { As Restated }\end{array}$ \\
\hline
\end{tabular}

LAPORAN POSISI KEUANGAN KONSOLIDASIAN (lanjutan):

EKUITAS

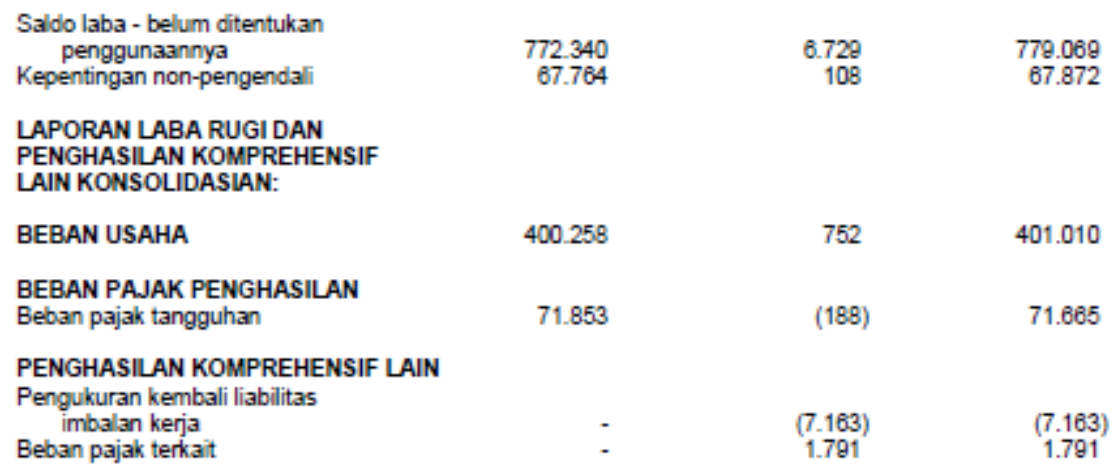

Gambar 4

Penyajian Kembali Laporan Keuangan 
Analisis

Pengakuan,

Pengukuran dan

Pengungkapan

Imbalan Pasca

Kerja

Berdasarkan

PSAK No. 24

(revisi 2013) dan

Dampak

Perubahannya

terhadap

Laporan

Keuangan Pada

Perusahaan

Yang Terdaftar

Dalam Bursa

efek Indonesia

\section{5}

(1) Pada tahun 2014 jumlah Liabilitas Imbalan Kerja PT.Blue Bird senilai 73.496 yang masih menggunakan PSAK No.24 (revisi 2010). Setelah perusahaan menerapkan PSAK No.24 (revisi 2013) adanya penyajian kembali di tahun 2015 sebesar 64.379 yang terdapat suatu penyesuaian sejumlah (9117).

(2) Karena terdapat pengukuran kembali liabilitas imbalan kerja maka perusahaan mengakui Other Comprehensive Income yang disajikan pada tahun 2015 sebesar 3.779 (terdapat di mutasi laporan possisi keuangan konsolidasian). dan keuntungan dan kerugian aktuarial yang diakui sebagai beban disajikan kembali di akhir 31 Desember 2014 sebesar (7.163).

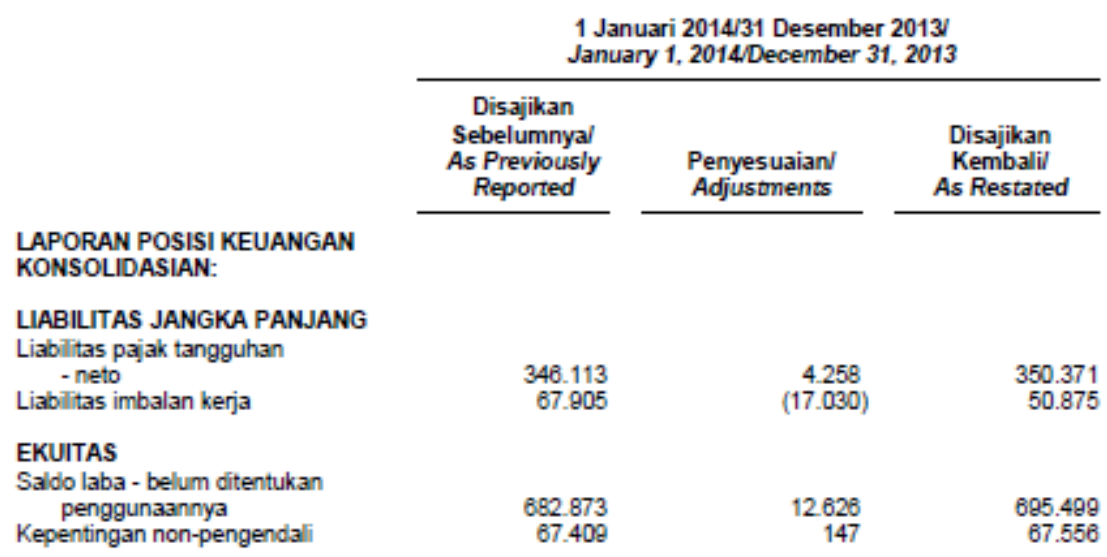

Gambar 5

Penyajian Kembali Laporan Keuangan Liabilitas-Ekuitas

Pada tahun 2013-2015, terdapat penyajian kembali liabilitas imbalan kerja yang sebelumnya pada tahun 2013 disajikan sebesar 67.905 dan pada awal bulan Januari 2014 sebesar 50.875, terdapat penyesuaian sebesar (17.030).

\section{SIMPULAN DAN SARAN}

\section{SIMPULAN}

Berdasarkan hasil analisis yang dilakukan pada PT Telekomunikasi Indonesia. Tbk dan PT. Blue Bird. Tbk, maka dapat ditarik beberapa simpulan sebagai berikut.

1. PT. Telekomunikasi Indonesia.Tbk

a. Dalam menerapkan program imbalan pasca kerja, sudah menggunakan Program Iuran pasti dan Imbalan pasti.

b. Dalam menentukan program imbalan pasti terdapat beberapa asumsi yaitu: tingkat diskonto, tingkat kenaikan kompensasi dan taksiran tingkat pengembalian jangka panjang

c. Keuntungan dan kerugian aktuaria diakui sebagai pendapatan atau beban apabila akumulasi keuntungan atau kerugian aktuaria bersih yang belum diakui pada akhir tahun pelaporan sebelumnya melebihi $10 \%$ dari nilai kini imbalan pasti. Keuntungan atau kerugian ini diakui dengan menggunakan metode garis lurus berdasarkan sisa masa kerja rata-rata karyawan.

d. Pengakuan, pengukuran dan pengungkapan telah diterapkan perusahaan sesuai dengan ketentuan PSAK No. 24

e. Perusahaan telah menerapkan PSAK No. 24 (Revisi 2013). 
2. PT. Blue Bird. Tbk

a. Dalam menerapkan program imbalan pasca kerja, sudah menggunakan Program Imbalan pasti.

b. Dalam menentukan program imbalan pasti terdapat beberapa asumsi yaitu: tingkat diskonto, usia pensiun, kenaikan gaji, tingkat mortalitas, tingkat cacat dan tingkat pengunduran diri.

c. Terdapat faktor-faktor penentu dari jumlah nilai kini kenaikan imbalan pasti, seperti: biaya jasa lalu, biaya jasa kini, biaya bunga, keuntungan dan kerugian aktuarial. Ketika terjadi keuntungan aktuaria, maka keuntungan tersebut diakui langsung sebagai penghasilan komprehensif lain. Penghasilan tersebut tidak dapat diakui dalam laba rugi. Berbeda dengan ketentuan PSAK No. 24 (revisi 2010) yang masih menggunakan pendekatan koridor.

d. Pengakuan, pengukuran dan pengungkapan telah diterapkan perusahaan sesuai dengan ketentuan PSAK No. 24

e. Perusahaan telah menerapkan PSAK No. 24 (Revisi 2013).

\section{SARAN}

Beberapa saran yang dapat diberikan berdasarkan hasil penelitian ini adalah :

a. Sebaiknya perusahaan terus mengikuti perkembangan standar akuntansi yang berlaku umum di Indonesia dan perkembangan terbaru dari undang-undang ketenagakerjaan serta peraturan-peraturan lainnya yang berhubungan dengan pemberian imbalan kerja.

b. Tetap konsisten terhadap penerapan PSAK terlebih khusus dalam hal ini penerapan PSAK No. 24 dikarenakan imbalan kerja merupakan beban yang cukup besar bagi operasional perusahaan yang dapat langsung berpengaruh terhadap laba perusahaan dan likuiditas perusahaan, sehingga dibutuhkan pengungkapan yang jelas agar dapat tersaji informasi yang memadai untuk semua pihak yang berkepentingan, untuk membantu pengambilan keputusan yang tepat.

\section{DAFTAR PUSTAKA}

Dewan Standar Akuntansi Keuangan., PSAK 24 Imbalan Kerja (revisi 2013), IAI, Jakarta.

Dewan Standar Akuntansi Keuangan., PSAK 24 Imbalan Kerja (revisi 2013, par 1), IAI, Jakarta.

Dewan Standar Akuntansi Keuangan., PSAK 24 Imbalan Kerja (revisi 2013, par 3), IAI, Jakarta.

Dewan Standar Akuntansi Keuangan., PSAK 24 Imbalan Pasca Kerja (revisi 2013, par 8), IAI, Jakarta.

Martono.,2010, Bank dan Lembaga keuangan, Graha Ilmu, Jakarta.

Lisa,L.I., 2015. Analisis pengakuan, pengukuran dan pengungkapan imbalan kerja berdasarkan psak no.24 tentang imbalan kerja pada PT. hasjrat abadi manado. Vol 3 (4):385-393

Liapis, K., and Thalassinos, E., 2013. A Comparative Analysis for the Accounting Reporting of "Employee Benefits" between IFRS and other Accounting Standards: A Case Study for the Biggest Listed Entities in Greece. Vol 1 (1)

Marisi., 2005. Imbalan Pasca Kerja, Graha Ilmu, Jakarta,

Purba, M.P., 2012. Akuntansi dan Pelaporan Keuangan Imbalan Kerja, Graha Ilmu, Jakarta. 
Analisis

Pengakuan,

Pengukuran dan

Pengungkapan

Imbalan Pasca

Kerja

Berdasarkan

PSAK No. 24

(revisi 2013) dan

Dampak

Perubahannya

terhadap

Laporan

Keuangan Pada

Perusahaan

Yang Terdaftar

Dalam Bursa

efek Indonesia
Rahmania, D., 2014, Akuntansi Imbalan Paska Kerja Pada Pt Avia Avian, Sekolah Tinggi Ilmu Ekonomi Indonesia (Stiesia) Surabaya, Vol 3 (12)

Sugiyono., 2017, Pendekatan Deskriptif, Graha Ilmu, Jakarta.

Tawas, C. P. J., 2013, Akuntansi Pertanggung Jawaban Terhadap Imbalan Kerja

Menurut Psak No. 24 Pt Pegadaian (Persero) Cabang Manado Utara, Vol 1 (3):365-373

Watung, M.N., Nangoi,G.B., Pusung, R.J., 2016. Analisis Penerapan Psak 24 Mengenai Imbalan Kerja Pada Pt Bank Maybank Indonesia Tbk Kcp Kotamobagu, Vol 4 (4) 